\title{
THE ROLE OF GREEN INFRASTRUCTURES IN IMPROVING THE QUALITY OF LIFE IN THE UNIVERSITY CAMPUSES OF BUCHAREST
}

DOI: http://dx.doi.org/10.18509/GBP.2020.78

UDC: 378.4.096:502/504(498)

\author{
Alina Simion ${ }^{1,2}$ \\ Alexandra Grecu ${ }^{1,2}$ \\ Andreea Karina Gruia ${ }^{1,2}$ \\ Oana Elena Joița ${ }^{1,2}$ \\ Cristina Popescu ${ }^{1,2}$ \\ ${ }^{1}$ University of Bucharest - Faculty of Geography, Romania \\ ${ }^{2}$ University of Bucharest - Research Center for Integrated \\ Analysis and Territorial Management (CAIMT), Romania
}

\begin{abstract}
Probably one of the biggest challenges today is to make urban space a life-friendly environment and not a hostile environment. In this sense, urban green infrastructures play an extremely important role in increasing the quality of life and mitigating the negative effects caused by economic activities, overcrowding and transport. Unfortunately, however, we are witnessing a global reduction in green areas as a result of prioritizing the construction of buildings and roads, resulting a decrease in the number of square meters of green space allocated per capita.

In the present study we set out to capture the way that urban green infrastructures, located near or on the university campuses in Bucharest, could improve the quality of students' lives. Most of them are constantly facing the stress caused by factors coming from both the university and urban areas, but the green areas have an important role in reduction daily stress and even increase the cohesion of the community. We have analized two university campuses, located in Bucharest, who were considered as relevant for the research. For these, were analyzed the degree of accessibility of the students to the nearest parks, by creating a cartographic representation of the distance between them and campuses. Subsequently the map was used to determine the frequency with which these green spaces are visited and the reasons underlying these visits. Also, a questionnaire was created based on which we performed the spatial modeling of the two campuses taking into account the priority needs of the students (green areas, areas for study, areas for recreation, areas for sports).

As a result of the applied methodology, the increasing need for expansion and modernization of the existing urban green infrastructures was highlighted and the creation of new ones aimed at increasing the quality of life as a whole and for students in particular.
\end{abstract}

Keywords: green infrastructure, quality of life, urban space

\section{INTRODUCTION}

Cities are covering now almost $0.5 \%$ of our planet's land area and are expanding at twice their population growth rates, on average [1]. In present, over half of the world's population is living in urban areas and is estimated to increase at $68 \%$ by 2050 [2]. Cities who have known unprecedented growth are now experiencing severe environmental problems (e.g. noise, increasing urban heat island effect, carbon emissions, flooding or 
biodiversity loss) [3], [4], [5], [6] [7]. The pressure that cities ar subjected to as the population is increasing has often lead to urban sprawl [8] and also denser cities, in attempts to counterbalance the effect of urban sprawl [9], [10]. Denser cities or the "compact city" it predicates congested areas, reducing urban green space and increasing the urban heat island effect [11], [12], [9].

Urbanization together with a planning policy of spatial densification are making the urban population face the prospect of living in residential environments with little green space [13] such as parks, urban agriculture, urban forests, residential gardens, street trees or roof gardens [14], [15].

The green infrastructure concept is considered to be a multi-object strategic planning approach implementing at various scales different kinds of urban green spaces [16], [15]. The key features for green infrastructure concept is referring to a "(..) a strategically planned network of high quality natural and semi-natural areas with other environmental features, which is designed and managed to deliver a wide range of ecosystem services and protect biodiversity in both rural and urban settings". Categories of green infrastructure located in urban areas vary by structure and are defined by their surface and functions [17], [18]. The population living in cities can extract a large group of benefits from categories as parks, street trees, school green area, public institutions' gardens, residential gardens, cemeteries, sports grounds, squares, urban forests and also green spaces of the industrial and commercial production [18].

Is it known that Universities contribute for sustainability at internal (i.e., sustainability policy, campus sustainability, environmental initiatives, curricula, and research) and external (i.e., universities' role in the region) levels [19].

In present, university students are suffering from psychological or health problems that are caused by the change from a familiar environment to a new one. This problems have a background of academic, interpersonal, financial and cultural challenges that they are facing [20], [21]. Studies have shown that green spaces offered by university have the capability [22] to reduce stress levels, improve mental restoration [23], mental and psychological health, quality of life and well-being [24], [25], [21].

\section{METHODOLOGY}

\section{Location}

Bucharest is the biggest university center in Romania, having 33\% of the students in the country. The city is home for a variety of universities who have developed in recent years campuses for their students. The campuses are integrated in the urban structure and are found in number of 16 , belonging to public and private universities.

University campuses in Bucharest were analized and were selected two campuses from the biggest universities in the city, University of Bucharest and University Politehnica of Bucharest (Fig.1). The two campuses, Regie and Grozăvești are localisated at $3 \mathrm{~km}$ from the city center and were selected because together they are home for almost 20.000 students.

Firstly was analyzed the distance from the campuses to the nearest city parks. The World Health Organization suggests that people need a minimum of $9 \mathrm{~m}^{2} /$ capita and the European legislation adopted by Romania also sets the limit at $26 \mathrm{~m}^{2} /$ capita. Instead, according to WHO, the area that a person needs is $50 \mathrm{~m}^{2}$. These figures are only valid if people have access to the green spaces [25]. 


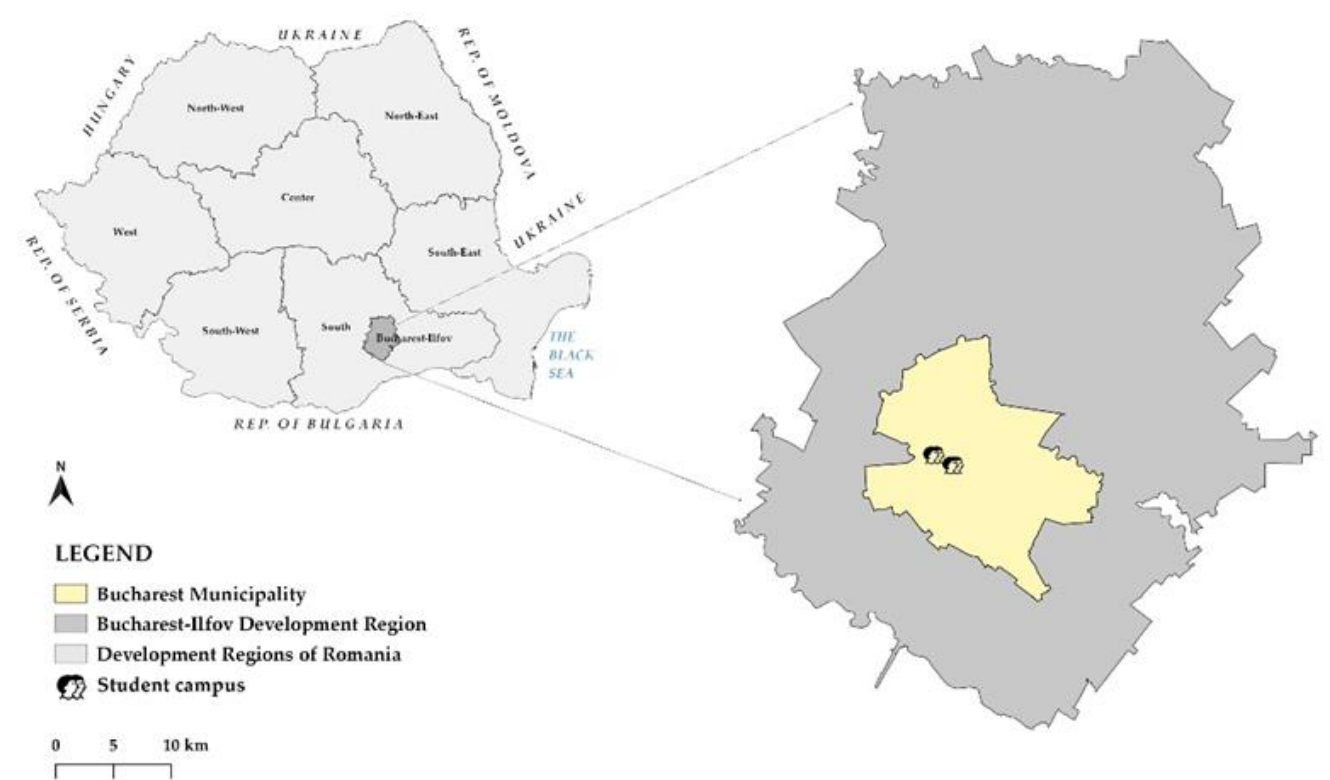

Figure 1. Campuses localisation in Bucharest

\section{Data}

The questionnaire method was used for the residents of the two student campuses to evaluate the general access to green spaces. Thus, in February 2019, a questionnaire dedicated to the students who are living in the campuses was launched online so the respondents were able to complete the questionnaire based on their availability. Also, the results of the questionnaire were verified by observing the campuses selected.

Table 1. Data extracted from the student campuses

\begin{tabular}{|c|c|c|}
\hline \multirow[b]{2}{*}{ Data } & \multicolumn{2}{|l|}{ Campuses } \\
\hline & Grozăvești & Regie \\
\hline Number of students & 3.322 & 14.729 \\
\hline Total surface: & $80.461 \mathrm{~m}^{2}$ & $228.858 \mathrm{~m}^{2}$ \\
\hline Buildings & $33.322 \mathrm{~m}^{2}$ & $81.692 \mathrm{~m}^{2}$ \\
\hline Parking lots & $15.348 \mathrm{~m}^{2}$ & $17.075 \mathrm{~m}^{2}$ \\
\hline Concrete areas & $7.850 \mathrm{~m}^{2}$ & $8.494 \mathrm{~m}^{2}$ \\
\hline Green areas & $23.941 \mathrm{~m}^{2}(100 \%)$ & $121.597 \mathrm{~m}^{2}(100 \%)$ \\
\hline $\begin{array}{l}\text { Green surface with } \\
\text { active management }\end{array}$ & $8.799 \mathrm{~m}^{2}(37 \%)$ & $80.955 \mathrm{~m}^{2}(67 \%)$ \\
\hline $\begin{array}{l}\text { Green surface with } \\
\text { passive management }\end{array}$ & $15.142 \mathrm{~m}^{2}(63 \%)$ & $40.955 \mathrm{~m}^{2}(33 \%)$ \\
\hline Green area per capita & $7,18 \mathrm{~m}^{2} /$ capita & $8.25 \mathrm{~m}^{2} /$ capita \\
\hline Number of respondents & 199 & 100 \\
\hline $\begin{array}{l}\text { Closest green space that } \\
\text { student use }\end{array}$ & Campus ( $47 \%$ of the respondents) & $\begin{array}{l}\text { Campus }(42 \% \text { of the } \\
\text { respondents) }\end{array}$ \\
\hline Use of green space & $\begin{array}{c}\text { Walking }(55 \%) \text {, social activities, } \\
\text { recreation }\end{array}$ & $\begin{array}{l}\text { Walking }(54 \%) \text {, social } \\
\text { activities, recreation }\end{array}$ \\
\hline $\begin{array}{l}\text { Limitations in using the } \\
\text { campuses green space }\end{array}$ & $\begin{array}{l}\text { Aesthetic aspect, lack of suitable } \\
\text { equipment for recreation and sports }\end{array}$ & $\begin{array}{l}\text { Aesthetic aspect, lack of } \\
\text { suitable equipment for } \\
\text { recreation and sports }\end{array}$ \\
\hline Existing facilities & Socialization areas, commercial areas & $\begin{array}{c}\text { Socialization areas, } \\
\text { commercial areas }\end{array}$ \\
\hline Student's needs & $\begin{array}{l}\text { Esthetic green spaces, studying areas, } \\
\text { sports areas, event areas, street furniture }\end{array}$ & $\begin{array}{l}\text { Esthetic green spaces, } \\
\text { studying areas, sports areas, } \\
\text { event areas, street furniture }\end{array}$ \\
\hline
\end{tabular}




\section{RESULTS}

Firstly was analyzed the distance from the campuses to the nearest city parks. Researchers have calculated the distance at which parks should be located based on their surface area. Thus, Van Herzele and Wiedemann consider that the parks between 0.15 and 1 ha should be located at a distance of $250 \mathrm{~m}$, between $1-3$ ha at a distance of $500 \mathrm{~m}, 3-10$ at a distance of $1,000 \mathrm{~m}$, and areas larger than 10 ha do not have a specified limit [26].

Having this classification as a model, we have increased the distance and made a mape (Fig. 2.) for the nearest parks using the following distance values: $0-1000 \mathrm{~m}, 1000-2000 \mathrm{~m}$ and 2000-3000m.

Based on the map we have extracted the following informations about the parks located near the two universities campuses:

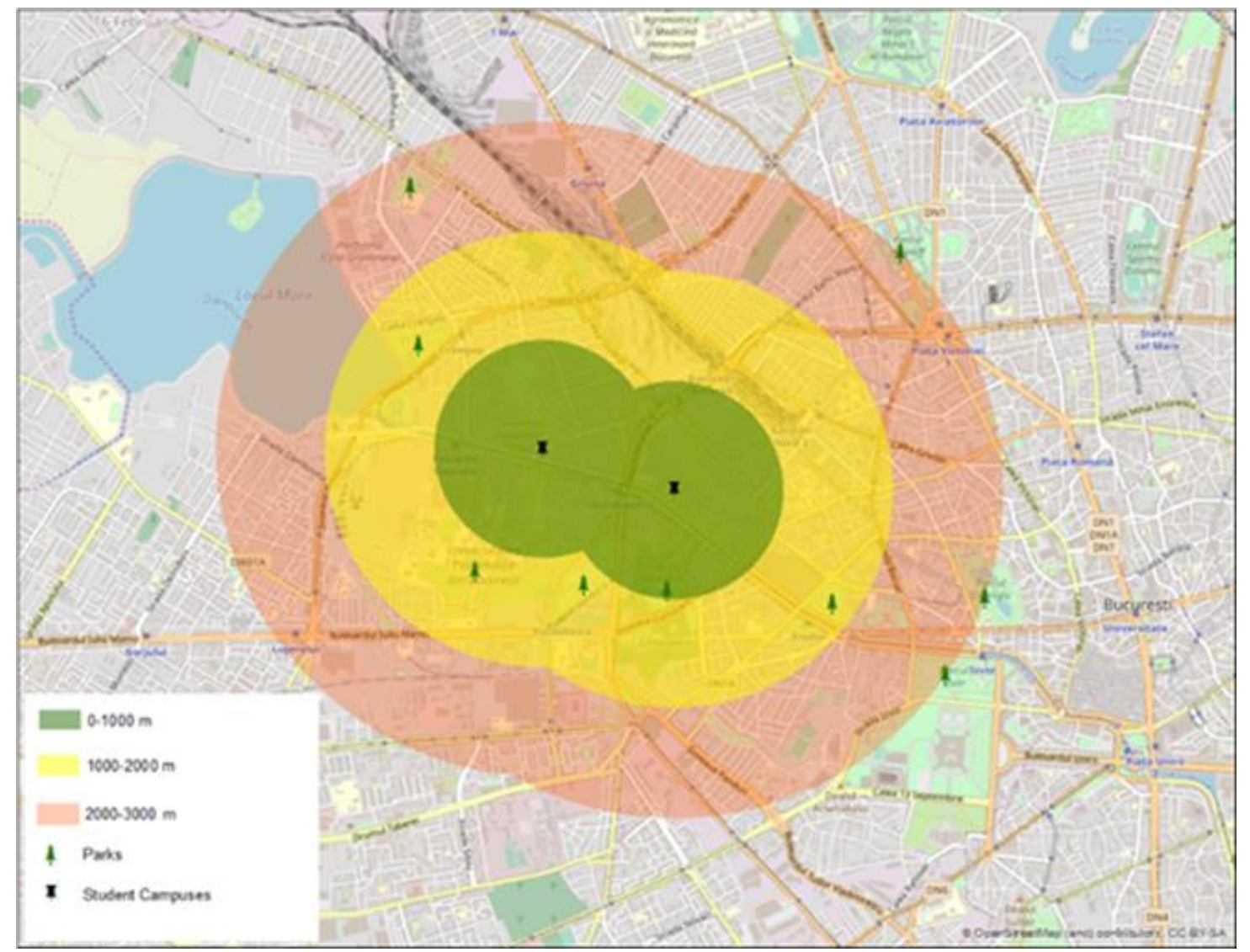

Figure 2. Localization of Grozăvești and Regie campuses in relation to the parks nearby

Table 2. Green surface near the campuses

\begin{tabular}{|c|c|c|}
\hline Distance & Green surface & Surface (ha) \\
\hline $0-1000 m$ & - & \\
\hline \multirow{5}{*}{$1000-2000 m$} & Grozăvești Park & 3 \\
\hline & Opera Park & 3,5 \\
\hline & Crângași Park & 6 \\
\hline & Botanical Garden & 17,5 \\
\hline & Politehnica Park & 40 \\
\hline \multirow{3}{*}{$2000-3000 m$} & Giulești Park & 4 \\
\hline & Cișmigiu Park & 16 \\
\hline & Izvor Park & 17 \\
\hline
\end{tabular}


According to the data collected through questionnaires, campuses are the green areas that students frequently use. The parks have a low level of use because of the distance they are located, most of the students prefer the green areas inside the campuses due to their proximity. In most cases, campuses do not fully meet the needs of students due to lack of facilities.Using the results of the questionnaires and also the field observation we managed to see what surfaces of the campuses could be reconverted using green infrastructure elements to meet the student's needs.

a) Grozăvești Campus

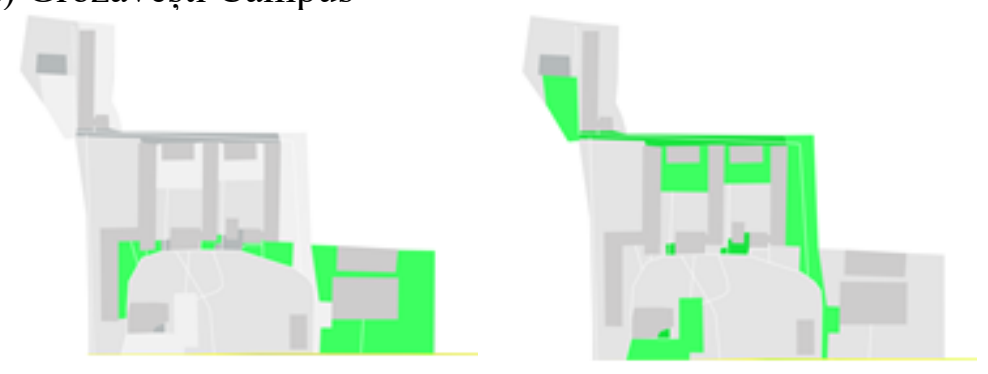

Area 1

Area 2

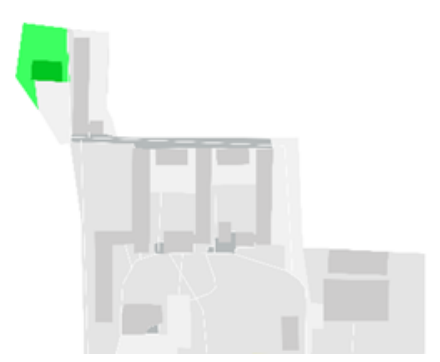

Area 3

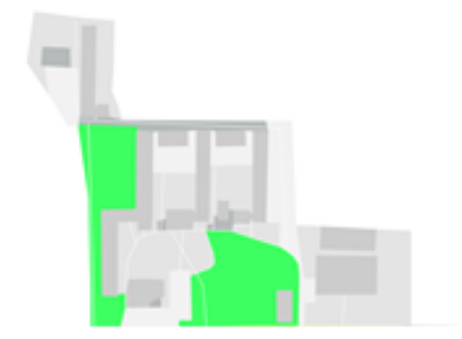

Area 4

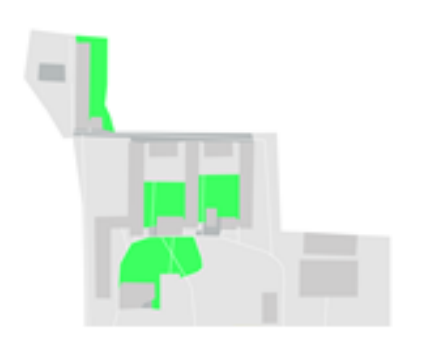

Area 5

b) Regie Campus

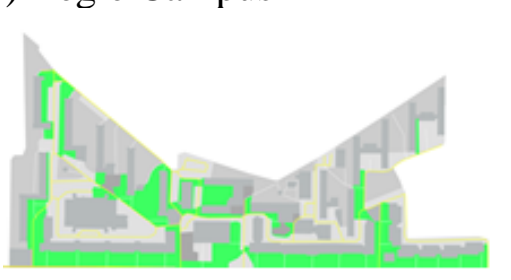

Area 1

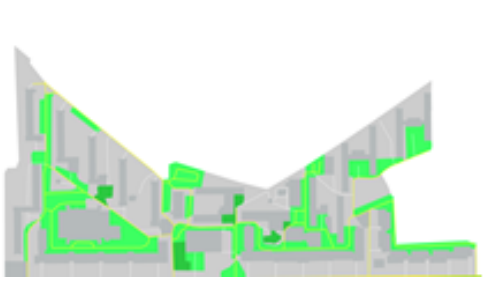

Area 2

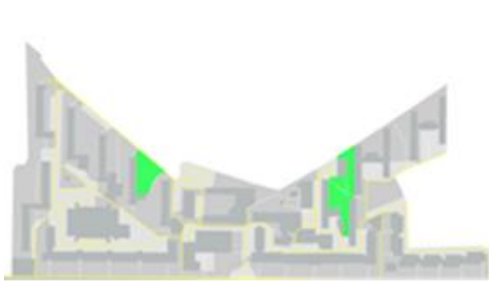

Area 3

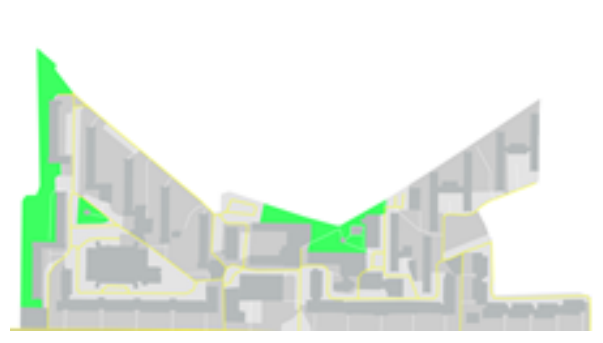

Area 4

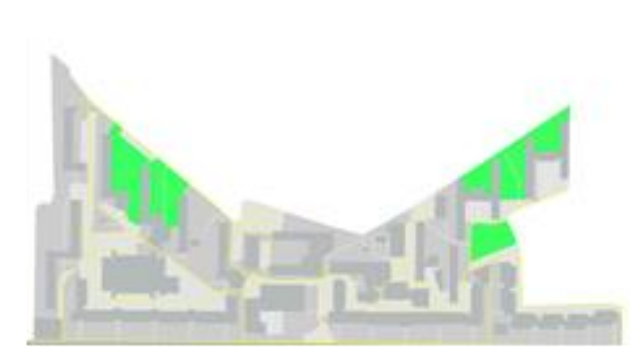

Area 5 
Table 3. Green infrastructure proposals

\begin{tabular}{|c|c|c|c|c|c|}
\hline Name & Surface & $\left(\mathbf{m}^{2}\right)$ & $\begin{array}{c}\text { Current } \\
\text { utilisation }\end{array}$ & $\begin{array}{c}\text { Reconversion } \\
\text { using green } \\
\text { infrastructure } \\
\text { elements }\end{array}$ & Benefits \\
\hline & Grozăvești & Regie & & & \\
\hline Area 1 & 4.132 & 46.967 & $\begin{array}{l}\text { Gardens with } \\
\text { passive } \\
\text { management }\end{array}$ & $\begin{array}{c}\text { Gardens with } \\
\text { active management }\end{array}$ & $\begin{array}{c}\text { Improves } \\
\text { aesthetic } \\
\text { appearens, } \\
\text { encourages long } \\
\text { walks }\end{array}$ \\
\hline Area 2 & 23.198 & 25.569 & $\begin{array}{l}\text { Parking lots and } \\
\text { concret areas }\end{array}$ & $\begin{array}{l}\text { Bioretention } \\
\text { system for } \\
\text { rainwater }\end{array}$ & $\begin{array}{c}\text { Control } \\
\text { stormwater } \\
\text { runoff, removes } \\
\text { heavy polluants } \\
\text { from car leaks }\end{array}$ \\
\hline Area 3 & 2.371 & 18.764 & $\begin{array}{l}\text { Abandoned } \\
\text { football field } \\
\text { and passive } \\
\text { management } \\
\text { green area }\end{array}$ & $\begin{array}{c}\text { Recreation and } \\
\text { sport area with } \\
\text { active management } \\
\text { of green spaces }\end{array}$ & $\begin{array}{c}\text { Encourages } \\
\text { social events and } \\
\text { spending time in } \\
\text { the nature }\end{array}$ \\
\hline Area 4 & 4.144 & 11.829 & $\begin{array}{c}\text { Passive } \\
\text { manangement } \\
\text { green spaces }\end{array}$ & Recreation area & $\begin{array}{c}\text { Improves } \\
\text { aesthetic } \\
\text { appearens, } \\
\text { encourages long } \\
\text { walks }\end{array}$ \\
\hline Area 5 & 4.108 & 26.284 & $\begin{array}{c}\text { Passive } \\
\text { manangement } \\
\text { green spaces }\end{array}$ & Study area & $\begin{array}{l}\text { Improves mental } \\
\text { health and } \\
\text { learning } \\
\text { capacity }\end{array}$ \\
\hline
\end{tabular}

\section{CONCLUSIONS}

Land conversion into commercial or residential areas has lead to a decrease of green soaces, including parks, in the city of Bucharest [27]. In the urban area parks cover 3,3\% (812 ha) and are unevenly distributed within residential spaces [27], [28].

The green spaces from the university campuses are the solution to improve the well-being and health of students. The main purpose of the campuses is precisely to ensure a conducive environment for the students to carry out their study activities.

Thus, the university campuses should have available study spaces, recreation areas, sports areas, as well as gardens, in Romania there is a low percentage of educational institutions that invests in green spaces on university campuses, considering them to some extent, insignificant.

Through this paper we tried to evaluate the two student campuses, to identify the students' needs and to propose a green infrastructure elements to increase their level of comfort within the campuses.

We found through the questionnaire an increased interest of students for green spaces on campus and especially for their aesthetics. We could also notice the weak, even nonexistent, involvement of staff in the administration of educational institutions that do not provide support in the good management of green spaces. This fact is also due to the 
existence of other problems that are much more pressing in the university campuses than the lack of active management of the green spaces, considering them priority for solution. Elements of green infrastructure in the campuses are simple ways in which the comfort of students can be increased, but in order to be implemented there must be active involvement from administration of universities.

\section{REFERENCES}

[1] Angel, S., Parent, J., Civco, D. L., Blei, A., \& Potere, D. The dimensions of global urban expansion: Estimates and projections for all countries, 2000-2050. Progress in Planning, 53-107, 2011.

[2] United Nations, U. World Urbanization Prospects. The 2018 Revision. New York: United Nations. The Departament of Economic and Social Affairs, 2018.

[3] Odum, E. Fundamentals of ecology. Philadelphia: Saunders, 1971.

[4] Odum, H. Environment, Power and Society for the Twenty First Century: TheHierarchy of Energy. New York: Columbia University Press, 2007.

[5] Foster, J. The ecology of destruction. Monthly Review, pp1-14, 2007.

[6] Young, R. Managing municipal green space for ecosystem services. Urban Forestry \& Urban Greening, pp 313-321, 2010.

[7] Diaconu D.C., Peptenatu D., Pintilii R.-D., Andronache I., Drăghici, C.-C., Dobrea, R.-C. Analysis of the Relationship between the Piezometric Level and Urban Development in the Emerging Bucharest City, Romania, Procedia Engineering, vol. 190, 2017, p. 627-631.

[7] Sonde, P., Balamwar, S., \& Ochawar, R. Urban sprawl detection and analysis using unsupervised classification of high resolution image data of Jawaharlal Nehru Port Trust area in India. Remote Sensing Aplications: Society and Environment, 2019.

[8] Gavrilidis, A. A., Niţă, M. R., Onose, D. A., Badiu, D. L., \& Năstase, I. I. Methodological framework for urban sprawl control through sustainable planning of urban green infrastructure. Ecological Indicators, pp 67-78, 2019.

[9] Brueckner, J. K. Urban sprawl: diagnosis and remedies. International Regional Science Review, pp 160-171, 2000.

[10] Anguluri, R., \& Narayanan, R. Role of green space in urban planning: Outlook towards smart cities . Urban Forestry and Urban Greening, pp 58-65, 2017.

[11] Gunawardena, K., Wells, M., \& Kershaw, T. Utilising green and bluespace to mitigate urban heat island intensity. Science of The Total Environment, pp 1040-1055, 2017.

[12] Maas, J., Verheij, R., de Vries, S., Spreeuwenberg, P., \& Schellevis, F. Morbidity is related to a green living environment. Journal of Epidemiology \& Community Health , pp 967-973, 2009.

[13] Breuste, J., Haase, D., \& Elmqvist, T. Urban landscapes and ecosystem services. Ecosystem Services in Agricultural and Urban Landscapes, pp 83-104, 2013.

[14] Artmann, M., Kohler, M., Meinel, G., Gan, J., \& Ioja, C. How smart growth and green infrastructure can mutually support each other - A conceptual framework for compact and green cities. Ecological Indicators, pp 10-22, 2019.

[15] Hansen, R., \& Pauleit, S. From multifunctionality to multiple ecosystem services? a conceptual framework for multifunctionality in green infrastructure planning for urban areas. AMBIO, pp 516-529, 2014.

[16] European Commission, E. Building a Green Infrastructure for Europe. https://ec.europa.eu/environment/nature/ecosystems/docs/green_infrastructure_broc.pdf. 
[17] Badiu, D.L.; Iojă, C. I.; Pătroescu, M.; Breuste, J.; Artmann, M.; Niță, M. R.; Grădinaru, S.R.; Hossu, C. A.; Onose, D. A. Is urban green space per capita a valuable target to achieve cities' sustainability goals? Romania as a case study. Ecological Indicators, pp 53-66, 2016.

[18] Dagiliūte, R., \& Liobikienè, G. University contributions to environmental sustainability: challenges and opportunities from the Lithuanian case. Journal of Cleaner Production, pp 891899, 2015.

[19] Beiter, R., Nash, R., McCrady, M., Rhoades, D., Linscom, M., Clarahan, M., \& Sammut, S. The prevalence and correlates of depression, anxiety, and stress in a sample of college students. Journal of Affective Disorders, pp 90-96, 2015.

[20] Liu, Q.; Zhang, Y.; Lin, Y.; You, D.; Zhang, W.; Huang, Q.; Konijnendijkvan den Bosch, C.C.; Lan, S. The relationship between self-rated naturalness of university green space and students' restoration and health. Urban Forestry \& Urban Greening, pp 259-268, 2018.

[21] Lau, S., \& Yang, F. Introducing healing gardens into a compact university campus: design natural space to create healthy and sustainable campuses. Landscape Research, pp 55-81, 2009.

[22] Felsten, G. Where to take a study break on the college campus: An attention restoration theory perspective. Journal of Environmental Psychology, pp 160-167, 2009.

[23] Hipp, J., Gulwadi, G., Alves, S., \& Sequeira, S. The relationship between perceived greenness and perceived restorativeness of university campuses and student-reported quality of life. Environment and Behavior, pp 1292-1308, 2016.

[24] McFarland, A., Waliczek, T., \& J.M., Z. The relationship between perceived greenness and perceived restorativeness of university campuses and student-reported quality of life. HortTechnology, pp 232-238, 2008.

[25] Morar, T., Radoslav, R., Spiridon, L. C., \& Păcurar, L. Assessing pedestrian accessibility to green space using GIS. Transylvanian Review of Administration Science, pp 116-139, 2014.

[26] Van Herzele, A., \& Wiedemann, T. A monitoring tool for the provision of accessible and attractive urban green space. Landscape and Urban Planning, pp 109-126, 2003.

[27] Iojă, C., Grădinaru, S., Onose, D.A., V. G., \& Tudor, A. The potential of school green areas to improve urban green connectivity and multifunctionality. Urban Forestry and Urban Greening, pp 704-713, 2014.

[28] Iojă, C.I., Pătroescu, M., Niță, M.R.; Rozylowicz, L., Vânău, G.O., Iojă, A., Onose, D.A. Categories of residential spaces by their accessibility to urban parks-indicator of sustainability in human settlements case study: Bucharest. WSEAS Transactions on Environment and Development, pp 307-314, 2010. 